\title{
THE PRINCIPLE OF DOUBLE IDEALIZATION OF ANTIQUITY IN GEORG BÜCHNER'S DRAMA “DANTON'S DEATH”
}

\author{
(C) M. K. Menshikova \\ Lobachevsky State University of Nizhny Novgorod \\ 23 Gagarina prospekt, 603950, Nizhny Novgorod, Russia. \\ E-mail: menshikova4@yandex.ru
}

\begin{abstract}
In this article we analyze Georg Büchner's tragedy "Danton's Death" on the basis of implementation of double idealization principle as meaning-and structure-forming item of the text. It is proved that the principle of double idealization is connected with the antiquity; from the one hand, Ancient Greece comes out as a self-sufficient timeless ideal, opposed to the temporal ideal of Ancient Rome in the Republic period; on the other hand, the double idealization principle can be considered as a method applied during the formation of the new (in the historical context) ideal. However, in the world - which is interpreted by the dramaturge as the supremacy of chaos and fatalism of history, antiquity is once again is a constant point, from which the motion can start.
\end{abstract}

Keywords: Georg Büchner, dramaturgy, genre, double idealization.

Georg Büchner (1813-1837) - was one of the brightest figures of the German culture in the 19th century; an experimenter and innovator of the historic drama [1] and comedy genre; he anticipated many theatrical tendencies of the 20th century, including the theatre of the Absurd [2]; furthermore, he was a biologist, a university professor, an author of the textbook on comparative anatomy, an active participant of political events in Germany.

His activity goes beyond literature, his artistic methods - beyond concrete tendency. It's noteworthy that in modern science and art there is a significant and versatile interest in George Büchner's heritage.

Here are several examples of it: there is an annual edition of «Georg Büchner Jahrbuch» [3, 4] where one can find articles devoted to the tragedy "Danton's Death" (Danton's Tod, 1835). Among them the following edition should be mentioned: A. Schonlau's “Nimmt einer ein Gefühlchen”: Die Emotionen der Französischen Revolution in Georg Büchners Metadrama "Danton's Tod" [3, S. 337-340] and Milz Ch. "Eros und Gewalt in Danton's Tod" [3, S. 25-38]. Among the Russian researches two recent dissertations should be enumerated: "The artistic world of George Büchner" by E. V. Moskvina [5] and "G. Büchner's metadrama and its stage incarnation" by A. V. Savitsky [2].

G. Büchner is still topical even on the modern stage (although his first drama works were staged only at the beginning of the 20th century, almost a year after they had been written).

The "Büchnerbühne" theatre (situated in Büchner's hometown Hesse) worked out a joint Geman-french-polish project dedicated to Büchner's 200th anniversary and called it «Freiheit, Gleichheit, Brüderlichkeit - Eine Erinnerung an Europa». It is based on Büchner's novel “Danton's Death" and it was performed for the first time on the 17th of October, 2013.

Thus, his anniversary gives another reason to appeal to the artistic heritage of this ingenious writer and person.

In this article our attention will be paid to the principle, which is reflected in Büchner's dramaturgy - the principle of double idealization. Thus, it is naturally to consider particularly the tragedy "Danton's Death" where, from our point of view, the principle of double idealization of antiquity be- 
comes one of the meaning- and structure-forming items of the text. The tragedy "Danton's Death" [6] was written in 1835 and addressed the material of relatively not-so-distant past to the period of the French revolution, more exactly to 1794, the time of the Jacobin dictatorship. The transition of the conflict from the specifically-temporal level to the level of philosophy (or, ontological) is connected with the timeless idealization.

Ancient Greece here is the utopian ideal; it is noteworthy that the author of the play considers just like ancient Greeks - the past of Greece to be ideal, not the future. It should be underlined, that the opposition between Ancient Greece and Ancient Rome is clearly defined. Hereby, "Danton's circle" is 'marked' as much as possible by the Greece code, while "Robespierre's circle" - by the Roman one. This idea was expressed in Camille Desmoulins's cue right at the beginning of the play: Wir wollen nackte Götter, Bachantinnen, olympische Spiele, und melodische Lippen; ach, die gliederlösende, böse Liebe! Wir wollen den Römern nicht verwehren, sich in die Ecke zu setzen und Rüben zu kochen, aber sie sollen uns keine Gladiatorspiele mehr geben wollen [6, S. 11]. Another interesting example is the cue of Eros, which is said almost in the finale of the tragedy: Griechen und Götter schrien, Römer und Steiker machten die heroische Fratze [6, S. 143]. By the way, this phrase underlines one of the most important opposition criteria between ideological opponents of the tragedy: "Danton's circle" can show emotions, feelings - it can "shout" like "Greeks and Gods"; while Robespierre and his supporters are deprived of this - they look like statues. In this context properties of the Metadrama are reflected in Büchner's play. Usually, directors do not accentuate the socalled "ancient code" in their filmings or performances of the play, but Dimitri Buchowetzki cinematized it in 1921 with a discretely emphasized opposition between Danton's and Desmoulins's bright emotionality and expressivity, especially in mimicry and gestures and stiff characters of "Robespierre's circle" that resemble extant portraiture sculptures of Ancient Rome.

However, the idealization in George Büchner's tragedy does not mean absolute happiness and human's prosperity. Büchner's idea anticipates in many aspects Friedrich Nietzsche's thoughts on how the Greeks overcame all fears and horrors of existence by creating an artistic world of Olympic Gods: "From the titanic Gods of terror order with the help of Apollo's instinct of the beauty and in a slow transition developed the Olympic Gods of Joy order" [7, p. 58].

In this aspect Nietzsche's formula «amor fati» is also to be mentioned as it was supposed to indicate spiritual power of ancient Greeks, who were able to accept their fate and confront it due to their moral resources [8]. The second side of the implementation of the double idealization principle is the "potential" side which is connected with the above-mentioned aspect. This aspect of the tragedy is not noticeably expressed and it is connected with the motion towards the ideal; it has a vectorial direction to the other, higher world, but unlike timeless idealization it has temporal and local fixation. Moreover, it should be noted that in the tragedy there is neither romantic interpretation of the "higher world", nor religious aspect (despite references to a number of biblical characters). The idealization principle is shifted into the area of confrontation of ideas and becomes a higher step of cognition merged with preserved in Büchner's poetics elements of romantic irony. In this sense origins of the European "new drama" might have even an older history. The veritable nature of the revolution and the Republic turned into tyranny is interpreted by means of the "ancient code": the nation - "Minotaur"; the revolution - "Saturn Devouring his children" and "Daughters of Pelias"; the real freedom of the Republic for Robespierre is Clytemnestra and etc. At the same time, Robespierre's own character is always given in the context of Roman names and realia, except the situation when people called him Aristides, and as the tragedy advances, readers start to perceive it as an 
ironic characteristic. Name of the ancient Greek statesman and military leader of the period of the Greek-Persian war, for whom social issues and justice were mostly important, disharmonizes with Robespierre's other descriptions and characteristics; this foreignness contributes to the comprehension of his figure.

The aspect brought out here accounts for the great amount of reminiscences, allusions and hidden and direct quotations in the text that send the reader to not only to the ancient art and culture, but also to works of Shakespeare, Schiller, Sterne, Goethe, Schlegel, Brentano, Heine, Musset etc. if we take into consideration Büchner's other works, e.g. "Leonce and Lena” (1936). The use of quotations in Büchner's works is close to Théophile Gautier's idea that appeared in his poem "Un Vers de Wordsworth" (1832) in which one line from William Wordsworth's poem is found in the other text as a quotation which is not just alien, but even hostile to it. It gives rise to the conflict between the poetry and antipoetry, where the text becomes the main character [detailed \# 9]. The use of quotations by Büchner has a different orientation: in "Danton's Death" it serves as means of functioning of the romantic irony; creation of the tangible dissonance; in "Leonce and Lena" its role is to create relative and theatrical reality.

The cues of the drunken old man Simon addressed to curious passersby, his wife, or his daughter, who became a prostitute in order to provide for her family - is the brightest examples in the first play.

Simon's speech is full of words and phrases like: people of Rome, give me a dagger; vestal; Lucretia; Appius Claudius, Baucis etc. In this context discrepancy of the reference to the ideal character increases disharmony in the modern world; it is means of creating of the realistic picture of nation's life in the time of the Jacobin dictatorship.

The aspiration for the potential ideal in the tragedy is expressed in the incarnation of the idea of the humanism and compassion; hence ancient and Christian motives are on one side as in contrast to the terror and intimidation that aggravate human's existence in the world of chaos.

A special role is given to the motive of love, which is a generating element of the play. Thereby, Danton's love affairs are called "mosaic portrait" or an attempt to compose out of them Venus Medicean's character, or ideal, primordial image of love (Venus Medicean - is a Roman copy of the Greek statue, which portrays the Goddess of love that emerged from the spoondrift). Love in Büchner's work is presented in the unity of the spiritual and corporal principle as conforming to human's nature; love is the vector that defines the aspiration for the ideal in the modern world, so the idealization is provided not by means of direct reference to the antiquity, but by implementing archetypal elements in the character of Desmoulins's and Danton's wives - Lucille and Julie.

The double idealization principle accounts for the compositional orientation of the drama: from the first part, full of numerous semantic references to the antiquity, to the second postculminating part, where external theatricality and quotations are intensified, while irony combines with the elegiac mood, e.g. before the execution Eros says: Freue dich, Camille, wir bekommen eine schöne Nacht. Die Wolken hängen am stillen Abendhimmel wie ein ausglühender Olymp mit verbleichenden, versinkenden Göttergestalten [6, S. 145].

All in all, the double idealization principle in Georg Büchner's tragedy "Danton's Death" is connected with the antiquity: on the one hand, Ancient Greece is presented as self-sufficient, indisputable timeless ideal, as opposed to the temporal ideal of Ancient Rome in the Republic period; on the other hand, the double idealization principle can be considered as a method applied during the formation of the new (in the historical context) ideal. However, in the world - which is interpreted by the dramaturge as the supremacy of chaos and fatalism of history, antiquity is once again a constant point, from which the motion can start. 


\section{REFERENCES}

1. Armenkova O. A. Drama Georga Byukhnera «Smert' Dantona»v kontekste zapadnoevropeiskoi istoricheskoi dramy. URL: http://conf.phil.spbu.ru/Archives/book/2005/foreignlit/Armenkova.doc

2. Stavitskii A. V. Metadrama G. Byukhnera i problemy ee stsenicheskogo voploshcheniya: avtoref. dis. ...kand. iskusstvovedeniya. Saint Petersburg: Sankt-Peterburgskaya gosudarstvennaya akademiya teatral'nogo iskusstva, 2012.

3. Georg Büchner Jahrbuch. Band 11. 2005-2008. Walter de Gruyter, 2008.

4. Georg Büchner Jahrbuch. Band 12. 2009-2012. Hrsg. Dedner B., Gröbe. Moscow, Vering E. M., Walter de Gruyter, 2012.

5. Moskvina E. V. Khudozhestvennyi mir Georga Byukhnera: dis. ...kand. filol. n. Moscow: MPGU, 2007.

6. Büchner G. Danton's Tod. Dramatische Bilder aus Frankreich's Schreckensherrschaft. Frankfurt am Main. Druck und Verlag von J. D. Sauerländer, 1835.

7. Nitsshe F. Izbrannye raboty. Saint Petersburg: Azbuka-klassika, 2003. Pp. 40-144.

8. Sharypina T. A. Antichnost' v literaturnoi i filosofskoi mysli Germanii pervoi poloviny XX veka [Antiquity in Literary and Philosophical Thought in Germany of the First Half of 20th Century]. N. Novgorod: Izd-vo NNGU, 1998.

9. Zenkin S. N. Raboty po frantsuzskoi literature [Works on French Literature]. Ekaterinburg: Izd-vo Ural. un-ta, 1999. Pp. 170-200. 


\title{
ПРИНЦИП ДВОЙНОЙ ИДЕАЛИЗАЦИИ АНТИЧНОСТИ В ДРАМЕ ГЕОРГА БЮХНЕРА «СМЕРТЬ ДАНТОНА»
}

\author{
(C) М. К. Меньщикова
}

Нижегородский государственный университет им. Н. И. Лобачевского

Россия, 603950 г. Нижний Новгород, проспект Гагарина, 23.

E-mail: menshikova4@yandex.ru

В статье рассматривается трагедия «Смерть Дантона» немецкого писателя Георга Бюхнера с точки зрения реализации принципа двойной идеализации как смысло- и структурообразующего элемента текста. Доказывается, что принцип двойной идеализации связан с античностью: с одной стороны, образ античной Греции выступает как самодостаточный вневременной идеал, противопоставленный временному идеалу Древнего Рима в период Республики; с другой стороны, принцип идеализации может рассматриваться как приём, использующийся в процессе формирования нового (в историческом контексте) идеала, однако в мире, который драматург воспринимает, как господство хаоса и фатализма истории, константной точкой, от которой может быть начато движение, вновь становится античность.

Ключевые слова: Георг Бюхнер, драматургия, жанр, двойная идеализация.

Просьба ссылаться на эту работу как: Меньщикова М. К. Принцип двойной идеализации античности в драме Георга Бюхнера «Смерть Дантона» // Российский гуманитарный журнал. 2014. Т. 3. №1. С. 21-25. 